\title{
HUBUNGAN ANTARA KECERDASAN EMOSI DENGAN TINGKAT STRESS TERHADAP PROGRAM WAJIB ASRAMA DAN PENDIDIKAN SEMI MILITER PADA TARUNA POLITEKNIK ILMU PELAYARAN SEMARANG
}

\author{
Anis Setiyorini dan Joko Kuncoro \\ Fakultas Psikologi Universitas Islam Sultan Agung Semarang, Jalan Kaligawe Raya KM. 4, Semarang \\ Email: jkkuncoro4@gmail.com
}

\begin{abstract}
Abstrak
Tujuan dari penelitian ini untuk menguji secara empirik hubungan antara kecerdasan emosi dengan tingkat stress terhadap penerapan program wajib asrama dan pendidikan semi militer pada taruna politeknik ilmu pelayaran semarang. kecerdasan emosi merupakan kemampuan inidividu untuk dapat memahami diri sendiri, orang lain, mampu menjaga hubungan baik dengan orang lain dan dapat menetralisir stressor yang dialami. Stress merupakan ketidaksiapan individu menyesuaikan diri dengan perubahan. Hipotesis yang diajukan yaitu ada hubungan negatif antara kecerdasan emosi dan tingkat stress. Subjek pada penelitian ini adalah taruna yang sedang mengikuti program wajib asrama. Sampel penelitian berjumlah 145 taruna taruni. Metode pengumpulan data yang digunakan pada penelitian ini adalah skala, Skala Kecerdasan Emosi dan tingkat stress. Metode analisis data yang digunakan guna menguji hipotesis dengan metode korelasi Product Moment. Hasil uji hipotesis menunjukkan bahwa hipotesis ang diajukan diterima yaitu ada hubungan yang negatif antara kecerdasan emosi dan tingkat stress terhadap program wajb asrama dengan penerapan pendidikan semi militer dapat dilihat dari koefisien $r$ sebesar $-0,506$ dengan $p=0,000(p<0,01)$. Hasil ini menunjukkan adanya hubungan negatif yang signifikan antara kecerdasan emosi dengan tingkat stress.
\end{abstract}

Kata unci : Kecerdasan Emosi, Tingkat stress, Taruna

\section{RELATIONSHIP BETWEEN EMOTIONAL INTELEGENCE WITH STRESS LEVEL OF EDUCATION PROGRAM AND SEMI SEMI DORM MANDORATORY MILITARY SCIENCE CADETS IN MERCHANT MARINE POLYTECHNIC OF SEMARANG.}

\begin{abstract}
The research is exposing at the relation on the emotional question to the stress level on the compulsory application program in semi military on the cadets in Politeknik Ilmu Pelayaran Semarang. Emotional question emrances the individual ability to himselfes, to another and keeping good relation to others and can controlled the stress level itself or stressors. Stress is induvidual unreadiness in changing. Hypotesa proposes on the negative relation of emotional question and level stress. The research subject is semi military who follow the compulsory in the dormitory. Research ample includes 145 students. The collecting methode uses scale, emotional questions and stress level. The analysis for hypotesis measurment with the corellation methode product moment. The result shoows that hypnotyze accepted there will be negative emotional question and stress level to the compulsory program in the dorm and the semi military application program can see in the coeficiency $R$ that is $-0,056$ with $P=0,000$ ( $p>0,01)$. This result shows negative significant correlaton between emotional question to stress level.
\end{abstract}

Keyword : Emotional Question, stress level, semi military cadets

\section{Pendahuluan}

Indonesia terletak diantara dua benua dan dua samudera, serta warisan sejarah Bangsa Indonesia yang dapat disebut sebagai bangsa maritim dengan jumlah penduduk yang sangat besar, terdiri dari 16.508 pulau. Pelayaran merupakan pekerjaan yang memiliki peran penting dalam 
pelaksanaan angkutan penumpang dan barang. Maka dari itu pelayaran memiliki peran vital untuk mendukung kelancaran angkutan penumpang, maupun distribusi barang (Peraturan Menteri Perhubungan No.84 tahun 1993). Politeknik Ilmu Pelayaran meupakan sarana pendidikan untuk menghasilkan pelaut yang memiliki sumber daya manusia (SDM) yang baik, profesional dengan mental yang kuat. Pelaut merupakan individu yang memiliki keahlian sebagai awak kapal (Peraturan Menteri perhubungan No. 84 tahun 1993). Taruna merupakan mahasiswa yang bersekolah di kampus yang gaya pendidikannya dengan militer maupun semi militer.

Pendidikan di PIP dengan gaya penddikan semi militer karena taruna-taruni PIP dianggap sebagai perwira cadangan angkatan laut dan merupakan di bawah naungan kementrian. Pendidikan semi militer cenderung meniadakan nilai partisipasi dan cenderung menghilangkan demokrasi sehingga lebih banyak muncul kekerasan pendidikan semi militer yang di terapkan di PIP seperti : menerapkan pendidikan militer tersebut pada keseharian dalam proses belajar mengajar, atau dengan kata lain yang biasa dikenal di PIP adalah PHST (Perintah Harian Sifat Tetap) berpakaian militeristik lengkap dengan atribut seragam , junior yang harus hormat dengan senior, Instruktur (TNI AL), dosen, maupun staff, dikenai hukuman bagi taruna dan taruni yang melanggar aturan yang telah ditentukan. Hal tersebut dapat menyebabkan individu stress karena individu yang tidak memiliki kecerdasan emosi yang baik, maka individu tersebut akan mudah stress, depresi, membatasi diri dari lingkungan, tidak dapat mengontrol emosi akibat dari stressor tesebut.

Taruna taruni tidak diperkenankan membawa HandPhone (HP), bagi taruna taruni yang membawa HP dianggap melanggar peraturan dan akan dikenakan sanksi, sanksi yang diberikan oleh senior berupa pukulan, membersihkan toilet, mencuci, menalikan sepatu milik senior, lari keliling lapangan dan tidak diizinkan pesiar.

Pesiar merupakan jadwal bebas pada hari sabtu dan minggu yang diberikan untuk taruna yang sedang mengikuti wajib asrama, yang diperbolehkan mengikuti pesiar bagi taruna taruni yang tidak melanggar aturan ketika di asrama. Tidak hanya itu operasi mendadak yang dilakukan oleh para senior, instruktur (TNI AL) masuk ke dalam asrama, mengontrol tempat tidur ketika tengah malam (operasi dadakan), kerapihan dan seragam, waktu operasi yang dilakukan oleh senior, instruktur (TNI AL), waktu dan jamnya tidak dapat ditentukan, yang lebih sering ketika malam hari ketika taruna-taruni sedang beristirahat, sehingga taruna taruni tidak dapat menikmati waktu istirahatnya dengan tenang.

Kondisi-kondisi tersebut dapat memicu stress para taruna yang menempati asrama, namun tidak hanya pada saat menempati asrama saja yang mendapat hukuman, bagi taruna taruni yang sudah dapat meninggalkan asrama ketika melanggar aturan tetap dikenakan sanksi. Meskipun hal tersebut sudah menjadi kebiasaan namun tetap saja taruna taruni mengalami stress, merasa tertekan, takut, panik dan cemas, membutuhkan bantuan dari orang lain, marah, emosi namun tidak mampu melawan dan takut untuk memgambil resiko. Taruna dapat dikatakan stress karena taruna mengalami perubahan emosi negatif(tertekan ,takut dan cemas) dan perilaku yang dapat mempengaruhi kesehatan individu menurut See Baum (dalam Taylor,2009)

Menjadi taruna dan taruni harus kuat dengan segala sesuatu yang dilakukan harus dengan fisik, baik hukuman maupun kegiatan sehari-hari. Hukuman yang diberikan dengan pukulan atau tidak diperbolehkan keluar dari asrama berhari-hari bahkan sampai satu bulan. Dilarang menggunakan HP ketika di kampus maupun di asrama. Tidak diperbolehkan keluar asrama kecuali ke lingkungan kampus, tidak ada hiburan, memakai pakaian harus dengan atribut yang lengkap, terkadang tidak ada kesalahanpun tetap dicari kesalahannya oleh senior yang bertujuan membentuk kedisiplinan, hal tersebut yang membuat taruna stress serta memiliki keinginan untuk balas dendam, karena memendam emosi terhadap senior.

64 \begin{tabular}{l|l}
\hline E-ISSN 2656-4173 \\
P-ISSN $1907-8455$
\end{tabular} 
Hubungan Antara Kecerdasan Emosi Dengan Tingkat Stress Terhadap Program Wajib Asrama dan

Pendidikan Semi Militer Pada Taruna Politeknik IImu Pelayaran Semarang

Proyeksi, Vol. 14 (1) 2019, 63-73

\section{Tinjauan Pustaka \\ Kecerdasan emosi}

Menurut goleman (2006) kecerdasan emosi merupakan kecakapan dalam mengelola emosi yang meliputi kemampuan menendalikan emosi, memiliki kekuatan dalam mengahadapi tantangan, tidak cepat puas diri, dapat membina hubungan bauk dengan orag lain. Menurut Patton (2000) kecerdasam emosi merupakan kemampuan intelekual dan dasar-dasar pembentukan emosi dan mampu semangat untuk mencapai tujuan, empati terhadap orang lain, dan dapat memahami diri sendiri. Hutagalung (2002) kecerdasan emosi merupakan kemampuan untuk memberikan nilai merasakan serta memahami emosi . Hutagalung (2002) juga menyatakan bahwa individu yang memiliki kecerdasan emosi yang baik akan memiliki komitmen yang baik pula terhadap sesuatu yang sedang dikerjakan meskipun sedang dengan keadaan cemas . Goleman (dalam Nur 2008) menyatakan kecerdasan emosi merupakan kesiapan individu dalam menerima kegagalan, dan menahan emosi, dalam keadaan yang tidak sesuai dengan suasana hati.Agustian (2003) menyatakan bahwa kecerdasan emosi merupakan kemampuan individu dalam menerima stimulus yang mengakibatkan emosi, dan menjadikannya sebagai sumber informasi yang penting untuk memahami diri sndiri serta orang lain untuk mencapai tujuan. Prihastuti, dkk (2013) keceredasan emosi merupakan pemahaman terhadap diri sendiri, kemungkinan besar bahwa individu tersebut tidak menyukai perdebatan. Aspek-aspek kecerdasan Emosi Goleman (2006) menyatakan bahwa terdapat lima aspek kecerdasan emosi yaitu

a. Kesadaran diri

Kemampuan yag dimiliki individu untuk memahami peristiwa yang terjadi pada dirinya. Individu dapat meggunakan dan mengendalikan emosinya secara baik.

b. Mengelola Emosi

Individu mampu menyeimbangkan emosi yang dialaminya. Individu yang dapat mengelola emosinya yaitu individu yang dapat mengelola emosi negatifnya seperti kemarahan, kesedihan, dan kekecewaan.

c. Memotivasi diri

Kemampuan yang dimiliki individu yang dapat memberikan semangat untuk dirinya sendiri ketika individu tersebut sedang mengalami kekecewaan, kesedian, keputusasaan. Kemampuan memotivasi diri sendiri yang akan membuat idividu mampu bertahan dengan keadaan apapun.

d. Empati

kemampuan yang melekat pada diri individu untuk dapat mengetahui , memahami perasaan, pikiran orang lain,

e. Keterampilan sosial

yang dimiliki individu membina hubungan baik dengan orang lain, dapat mempertahankan interaksi dengan orang lain dan saling menghargai.

Goleman (2001) menyatakan terdapat empat faktor yang dapat mempengaruhi kecerdasan emosi yaitu :

a. Pengalaman

Kecerdasan emosi selalu berubah dengan bertambahnya waktu manusia berusaha menangani hati, dan menangani emosi individu sendiri serta orang lain.

b. Jenis kelamin

Dalam meningkatkan kecerdasan emosi, pria dan wanita memiliki kemampuan yang sama. Namun wanita lebih baik dalam peningkatan kecerdasan emosi ketika dihadapkan dengan 
masalah. Tetapi ada juga pria yang memiliki kecerdasan emosi yang baik. Meskipun dalam statistik terdapat berbedaan diantara keduanya pria dan wanita.

c. Usia

Taruna senior atau yang lebih tua memiliki kecerdasan emosi yang baik dari pada taruna yang masih junior.

d. Kedudukan

Semakin tinggi kedudukan individu akan semakin tinggi kemampuan mengelola emosi dan menonjol pada prestasinya. Sehingga dapat disimpulkan bahwa semakin tinggi jabatan maka semakin tinggi tingkat kecerdasan emosinya.

Ifham (2002) juga menyatakan ciri-ciri yang menyatakan individu yang memiliki kecerdasan emosi yang tinggi :

a. Optimis dan Berfikir Positif dalam menangani permasalahan yang ada dihidupnya yakin bahwa permasalahan yang dihadapi akan segera terselesaikan.

b. Terampil mengelola emosi, dapat mengendalikan emosi ketika dihadapkan dengan masalah dan situasi yang menegangkan, mengenali emosi diri sendiri dan memahami emosi orang lain.

c. Optimal dalam kecerdasan emosi yang meliputi hubungan antar pribadi, kreatif, mudah tanggap dan tangguh.

d. Mengedepankan nilai belas kasihan, empati intuisi dan integritas.

e. Mengoptimalkan kesehatan secara umum, misalnya kualitas hidup dan kerja yang optimal.

\section{Tingkat Stress}

Terdapat dua jenis stress menurut Selye (dalam Girdano,2005), yaitu eustress dan distress. Eustress merupakan hasil dari respon terhadap stress yang bersifat positif. Hal tersebut merupakan keberhasilan individu, beradaptasi secara fleksibel yang mendorong individu dalam beradaptasi dengan lingkungan. Ketika tubuh dapat mampu mengelola stress, dapat melewati performa maka stress tersebut bersifat baik.

Walker (2002) mengatakan bahwa distress merupakan ketidakmampuan mengatasi respon stress, sehingga individu tersebut merasa tertekan, sehingga dapat menyebabkan terjadinya gangguan psikologis dan fisiologis. Seseorang yang mengalami distress cenderung bertindak secara berlebihan, dan tidak dapat bertindak secara optimal

Wilkinson (2002) mengatakan stress terjadi disebabkan oleh beberapa faktor, diantaranya tegang, sedih, marah dan frustasi. Stress dapat berpengaruh buruk bagi seseorang terutama berdampak pada kesehatan, namun seseorang juga dapat beranggapan bahwa stress merupakan kesenangan.

Schrafer (2007) mengatakan bahwa stress merupakan ketidakmampuan menghadapi masalah yang berat yang dianggap mengancam individu baik dari faktor luar individu maupun dari dalam individu. Menurut Ogden (2001) stress merupakan ketidakmampuan individu terhadap perubahan yang dialami individu tersebut dalam kehidupan sehari-hari, adanya permasalahan dalam keluarga, tempat kerja, pendidikan, kebtuhan ekonomi dan lain sebagainya.

Swarth (2009) mengatakan manusia cenderung mendapatkan stress fisik dan psikologisnya, lingkungan dengan udara yang sanat dingin juga dapat mengakibatkan individu mengalami stress fisik. Gibson (1996) menyatakan bahwa aspek stress dapat dikelompokkan menjadi 3 yaitu :

a. Aspek Emosional : merupakan perasaan individu yang hanya mengalami frustasi, kecewa dan gelisah.

b. Aspek Kognitif : 
merupakan aktivitas yag berhubungan dengan kogitif atau pikiran seperti sulit berkonsenrasi tidak dapat fokus dengan satu hal saja.

c. Aspek Fisiologis :

merupakan masalah yang berkaitan dengan fisik, kadar gula naik, denyut jantung meningkat, tubuh menggigil. Aspek stress fisiologis juga dapat berbenyuk perilaku dengan cara makan berlebihan pada waktu stress.

Greenwood (dalam Yusuf, 2004) mengatakan bahwa terdapat beberapa faktor stress yang menyebabkan ketidakstabilan organisme seseorang baik dari luar maupun dari dalam. Berikut faktor yang menyebabkan ketidakstabilan organisme (stress) yaitu :

a. Faktor biologis stessor dari faktor biologis ini diantaranya pengalaman hidup, ritme biologis makanan, postur tubuh, faktor genetik dan penyakit.

b. Faktor psikologis yaitu faktor yang disebabkan karena pengalaman hidup, perasaan emosi, persepsi, pola perilaku dan menghindari masalah.

c. Faktor sosial yaitu faktor yang terdiri dari lingkungan fisik dan interaksi sosial.

Hardjana (dalam Sukoco, 2014) mengatakan bahwa seseorang yang stress memiliki gejala yang dapat di amati yaitu :

a. Gejala Fisik yaitu gejala stress yang berkaitan dengan fungsi fisik manusia dan kondisi tubuh.

b. Gejala Emosional yaitu gejala stress yang berkaitan dengan kondisi mental dan psikologis seseorang.

c. Gejala Intelektual yaitu gejala stress yang berkaitan dengan kognitif serta pola pikir seseorang.

d. Gejala Inter personal yaitu gejala yang berkaitan dengan hubungan dengan orang lain, membina hubungan baik dengan orang lain baik di dalam rumah maupun di luar rumah.

Ardani (2013) mengatakan terdapat dua cara menghadapi stress yaitu :

a. Cara menghadapi stress dalam perilaku

1) Memecahkan masalah dengan tenang

Mengevaluasi kegagalan dan stress yang bertujuan untuk mengurangi ancaman bahaya.

2) Agresi

Stress berpuncak pada emosi dan kemarahan. Contohnya mencari kambing hitam dan melampiasakan emosinya pada orang lain.

3) Kemunduran

Kondisi individu ketika stress akan mengalami kemunduran baik kemunduran secara perilaku maupun pemikiran. Individu yang mmengalami stress pada usia dewasa, cenderung memiliki perilaku yang jauh lebih muda dari usianya.

4) Menutup Diri

Respon yang sering digunakan alam mengambil sikap. Individu yang menutuo diri biasanya lebih memilih untuk tidak terbuka dengan siapapun dan tidak bertindak. Respon ini biasanya diikuti oleh sikap apatis.

5) Mengalihkan Perhatian

Individu yang mengalami stress yang berlebihan biasanya lebih sering mengelabuhi diri. Individu yang mengelabuhi diri ketika stress biasanya cenderung mengulangi perilaku tertentu secara berulang-ulang yang berguna untuk mengalihkan perhatian suapaya tidak terlihat bahwa dirinya setrss. 
b. Cara Menghadapi Stress Dari Segi Kognitif

1) Represi

Usaha untuk menghilangkan stress frustasi yang menyebabkan kecemasan.

2) Menyangkal kenyataan

Individu yang stress cenderung menyangkal kenyataan, menganggap bahwa kehidupannya tenang, dan tidak pengalaman yang buruk di kehidupannya.

3) Mengkhayal

Individu yang stress biasanya lebih sering mengkhayal dan menganggap khayalan tersebut akan menghilangkan frustasi dan stres yang dialami. Namun ketika stress terjadi berkhayal merupakan cara yang sehat untuk menghilangkan frustasi dan stress itu sendiri.

4) Rasionalisasi

Segala sesuatu yang dilakukan individu untuk berusaha menutupi kesalahannya supaya dapat diterima oleh lingkungan sosial.

5) Intelektualisasi

Individu yang menggunakan cara intelektualisasi akan menjadikan masalah sebagai pelajaran untuk dapat mencapai tujuan supaya masalah terebut tidak terlarut dengan permasalamahan emosi.

6) Reaksi

Individu yang berhasil menggunakan hal ini dapat menyembunyikan perasaan yang sesungguhnya baik represi maupun supresi dan ekspresi wajah yang tidak sesuai dengan suasana hati.

7) Proyeksi

Individu yang biasa menggunakan metode ini merupakan individu yang sering memperlihatkan ketidaksukaannya dengan orang lain.

Setiap individu memiliki perbedaan dalam merespon dan memprersepsikan stress. Persepsi individu didasarkan pada norma, pengalaman, faktor lingkungan dan keyakinan. Tingkat stress dapat dibagi menjadi lima bagian yaitu :

a. Stress Normal

Crowford (2003) menyatakan bahwa stress normal merupakan stress yang terjadi secara alami seperti stress karena kelelahan mengerjakan ujian, stress karena maju presentasi, takyt melakukan kesalahan, dan stress dikarenakan detak jantung yang berdebar-debar karena beraktivitas tinggi. Stress yan normal wajar terjadi, karena didalam kandunganpun individu sudah mengalami stress.

b. Stress Ringan

Psychology Foundation of Australia (2010) menyatakan bahwa stress ringan merupakan stress yang terjadi secara teratur dan berlangsung dengan waktu hitungan menit dan jam. Stress tersebut terjadi apabila dengan situasi macet di jalan raya, terlalu banyak tidur, dosen di kampus, terkena tilang karena melanggar hukum lalulintas. Stressor tersebut dapat mengaibatkan tremor ditangan, keringat dingin, denyut jantung yang sangat cepat dan tidak stabil, cepat merasa lemas, takut tanpa alasan yang jelas dan ketika stressor berakhir individu 
Hubungan Antara Kecerdasan Emosi Dengan Tingkat Stress Terhadap Program Wajib Asrama dan Pendidikan Semi Militer Pada Taruna Politeknik Ilmu Pelayaran Semarang Proyeksi, Vol. 14 (1) 2019, 63-73

tersebut merasa lega. Sehingga stressor ringan dapat megakibatkan individu terkena penyakit akibat stress.

c. Stress Sedang

Psychology Foundation of Australia (2010) menytakan bahwa stress sedang merupakan stress yang terjadi beberapa jam dan beberapa hari, biasanya masalah tersebut tidak dapat diselesaikan oleh bantuan teman maupun pacar stressor tersebut dapat menimbulkan mudah marah, berlebihan dalam bereaksi, gelisah, mudah tersinggung dan tidak sabar jika menunggu.

d. Stress Berat

Psychology Foundation of Australia (2010) menyatakan bahwa stress berat merupakan stress yang terjadi dalam jangka waktu yang lama beberapa minggu sampai beberapa tahun misalnya memiliki masalah dengan teman, senior dan dosen secara terus menerus keulitan ekonomi yang berkepanjangandan penyakit fisik. Jika stress terjadi secara berkepanjangan maka semakin tinggi resiko terkena stress. Stressor tersebut menimbulkan tidak dapat merasakan perasaan yang positif, selalu merasa tertekan, putus asa, tidak pernah merasa puas dengan hasil yang dicapai, merasa bahwa dirinya tidak bermanfaat.

e. Stress Sangat Berat

Stress sangat berat merupakan stress yang terjadi hitungan bulan bahkan sampai batas waktu yang tidak dapat ditentukan. Individu yang mengalami stress berat tidak memiliki motivasi untuk hidup.

\section{Taruna}

Sagita (2007) menyatakan bahwa taruna adalah siswa siswi yang menempuh pendidikan di semi militer maupun pendidikan militer, ketika lulus dapat disebut dengan perwira. Taruna PIP Semarang merupakan siswa siswi yang menempuh pendidikan di Politeknik IImu Pelayaran Semarang, yang terikat pada peraturan yang telah ditetpkan oleh kampus PIP Semarang. Berdasarkan peraturan dan kebijakan kampus PIP , bahwa taruna yang baru memasuki PIP semarang harus menempati asrama selama empat semester, setelah menempuh pendidikan selama empat semester, taruna wajib melaksanakan PRALA (praktik laut) selama satu tahun. Setelah taruna selesai menjalankan wajib PRALA, taruna wajib membuat laporan selama taruna melakukan PRALA di kapal. Untuk dapat menyandang sebagai perwira laut, taruna wajib mengerjakan tugas akhir, sebagai syarat yang di tentukan kampus untuk syarat kelulusan menjadi perwira laut.

\section{Pendidikan Semi Militer}

Pendidikan semi militer diberlakukan karena taruna-taruni dianggap sebagai perwira cadangan angkatan laut dan merupakan di bawah naungan kementrian Cubellis (1997). Pendidikan semi militer cenderung meniadakan nilai partisipasi dan cenderung menghilangkan demokrasi sehingga lebih banyak muncul kekerasan, pendidikan semi militer membutuhkan keteladanan seperti memberikan reward dan punishment yang sesuai, supaya tidak membuat stigma kekerasan dalam dunia semi militer pada masyarakat.

Politeknik Ilmu Pelayaran Semarang memiliki visi yang menyatakan bahwa PIP Semarang merupakan lembaga pendidikan unggulan di ASEAN. Misi Pendidikan Ilmu Pelayaran Semarang bertujuan mendidik dan melatih pemuda pemudi Indonesia menjadi Perwira Pelayaran Niaga dan 
Tenaga Ahli Angkutan / kepelabuhanan yang memiliki kompetensi sesuai Standart Nasional dan Internasional.

Politeknik Ilmu Pelayaran Semarang menerapkan pendidikan semi militer yang bertujuan untuk membentuk taruna dan taruni PIP Semarang menjadi calon perwira pelayaran yang hebat dan tangguh serta memiliki potensi yang baik. Pendidikan di PIP Semarang seperti pendidikan pada umumnya di kelas menjalankan pendidikan didalam ruangan, menggunakan metode ceramah, alat tulis, menggunakan LCD sebagai fasilitas yang mendukung perkuliahan. Di Politeknik Ilmu Pelayaran juga disediakan fasilitas laboratorium untuk taruna-taruni, mempelajari bagian-bagian dari perkapalan, taknik-teknik perkapalan hingga mempelajari alat navigasi kapal guna untuk memberikan dasar pengetahuan bagi taruna-taruni yang menempuh pendidikan di PIP Semarang.

Peraturan yang ketat dengan istilah pendidikan semi militer yang gaya pendidikannya menyerupai pendidikan militer pada umumnya, taruna-taruni yang menempuh pendidikan di PIP Semarang harus kuat secara fisik dan psikis, taruna-taruni dituntut untk melakukan latihan fisik setiap pagi hingga sore hari setelah perkuliahan selesai. Bagi taruna dan aruni yang melanggar peraturan yang telah ditetapkan oleh kebijakan kampus maka taruna-taruni tersebut harus siap menerima sanksi. Sanksi yang diterima untuk taruna-taruni yang telah melanggar peaturan dapat juga dikenakan hukuman fisik.

\section{Metode Penelitian}

Penelitian ini menggunakan metode deskripsi korelasi (Product Moment). Metode korelasi Product Moment diugunakan untuk dapat mengetahui hubungan antara kecerdasan emosi dan tingkat stress terhadap program wajib asama dan pendidikan semi militer di PIP Semarang. Populasi yang digunakan pada penelitian ini taruna taruni politeknik ilmu pelayaran semarang. Taruna taruni yang digunakan sebagai penelitian berjumlah 145 subjek penelitian.

Kriteria memilih sampel :

a. Taruna Politeknik Ilmu Pelayaran Semarang

b. Taruna yang sedang menjalankan wajib asrama ( Semester 1)

c. Bersedia mengikuti penelitian

\section{Instrumen}

Instrumen pada penelitian ini dengan menggunakan kuisioner yang terdiri dari 46 pernyataan mengenai kecerdasan emosional dan tingkat stress yang telah diuji validitas dan rebilitasnya. Kuisioner penelitian ini terdiri dari 25 pernyataan mengenai kecerdasan emosional dan 21 mengenai tingkt stress dengan mengunakan skala likert.

Validitas dan Reliabilitas

Validitas dari alat pengumpulan data (instrumen) sangat diperlukan sebelum digunakan dalam penelitian. Instrumen yang akan digunakan harus benar-benar dapat mengukur apa yang akan diukur. Kuisioner yang digunakan dalam penelitian ini dilakukan tes validitas, pada masing-masing item pada pertanyaan kuisioner. Uji validitas dapat dihitung dengan menggunakan rumus korelasi product moment Suyanto (2011:55). Untuk dapat melihat apakah instrument yang telah disusun, baik bila digunakan, maka perlu melakukan uji reliabilitas. Uji reliabilitas instrument dilakukan menggunakan rumus Alpha Cronbach karena dalam penelitian ini menggunakan instrumen penelitian dengan bentuk kuisionr dengan skala bertingkat Arikunto (2006:191) .

70 
Hubungan Antara Kecerdasan Emosi Dengan Tingkat Stress Terhadap Program Wajib Asrama dan

Pendidikan Semi Militer Pada Taruna Politeknik IImu Pelayaran Semarang

Proyeksi, Vol. 14 (1) 2019, 63-73

\section{Hasil dan Analisis}

Analisis yang digunakan untuk menganalisa data yaitu analisis Product Moment. Sebelum dilakukan analisis product moment dilakukan uji asumsi yang meliputi uji normalitas untuk sebaran dan uji lineartas hubungan. Uji Normalitas, tujuannya untuk menetahui normal dan tidaknya sebaran skor item pada skala kecerdasan emosi dan tingkat stress. Data yang diperoleh dari variabel penelitian diuji normalitas sebarannya yaitu dengan menggunakan teknik One-Simple Kolmogrov-Smirnov Test. Data yang dapat dikatakan berdistribusi normal apabila signifikasinya lebih besar dari 5 persen atau 0,05 . Hasil uji linearitas dengan menggunakan program SPSS 22.0 for Windows dengan teknik Compare Means menunjukkan nilai $F=4,127 ; p=0,000$. Hasil analisis data menunjukkan korelasi antara variabel Kecerdasan Emosional dengan variabel Tingkat Stress, dengan nilai $r=-0,056$ dengan $p=0,000$ $(p>0,01)$, sehingga hipotesis yang diajukan diterima. Deskripsi skor skala kecerdasan emosi yang diperoleh dalam penelitian ini secraa empirik yaitu skor minimum 44, skor maksimum 92, mean 79,32 dan standar deviasi 6,39. Deskripsi skor skala Tingkat stress yang diperoleh dalam penelitian ini secara empirik yaitu skor minimum 33, skor maksimum 82, mean 68,19 dan standar deviasi 6,80.

\section{Kesimpulan dan Saran}

Hasil dari penelitian ini dapat disimpulkan bahwa ada hubungan negatifyang signifikan antara kecerdasan emosi dengan tingkat stress pada taruna PIP Semarang semester dua. Dengan demikian hipotesis penelitian ini menyatakan bahwa ada hubungan yang positif secara signifikan antara kecerdasan emosi dan tingkat stress pada taruna PIP diterima. Sebagian besar subjek pada penelitian ini memiliki kecerdasan emosi dalam kategori tinggi dan pada tingkat stress dalam kategori sedang.

\section{Saran}

\section{Bagi Taruna}

Bagi taruna diharapkan untuk tetap semangat menjalankan kegiatan di asrama dan mentaati tata aturan di Politeknik Ilmu Pelayaran Semarang, tetap mempertahankan nilai sosial seperti menjaga hubungan baik dengan orang lain, berempati terhadap orang lain, dan dapat memotivasi diri sendiri dalam keadaan apapun, karena pada dasarnya pendidikan dan tata aturan yang ada di PIP memiliki tujuan yang sangat baik serta bermanfaat membentuk kedisiplinan, membentuk kemandirian, ketegasan dan membekali keahlian pelaut untuk taruna taruni calon cadangan angkatan laut (Pelaut).

\section{Bagi Kampus}

Bagi kampus PIP yang senantiasa membentuk taruna taruni dengan program wajib asrama dan semi militer dengan tujuan untuk membentuk kedisiplinan taruna-taruni baik untuk ditingkatkan dan mencoba menghilangkan stigma mengenai pendidikan semi militer yang dikenal oleh masyarakat sebagai pendidikan yang penuh dengan kekerasan dan balas dendam.

\section{Bagi Peneliti Selanjutnya}

Bagi peneliti selanjutnya yang hendak melakukan penelitian pada bidang ini, diharapkan untuk menjadikan penelitian ini sebagai perbandingan untuk penelitian selanjutnya yang membahas permasalahan yang diungkapkan pada penelitian ini. Hal lain yang perlu diperhatikan yaitu pembuatan aitem pada alat ukur skala yang digunakan dalam pengambilan data supaya dapat mendapatkan hasil yang yang lebih baik lagi supaya peneliti dan subek tidak memiliki persepsi yang berbeda. Peneliti-peneliti lain diharapkan menambahkan variabel-variabel yang akan diteliti. Selain itu juga perlu diperhatikan bahwa pelaksanaan penelitian baik tempat maupun waktu dapat mempengaruhi konsenrasi individu. 


\section{DAFTAR PUSTAKA}

Admin. 2007. "Memprediksi tingkat pengambilan investasi melalui rasio profitabilitas, likuiditas, dan leverage.

Alvin N.L.O. 2007. Handling study stress: pengembangan media bimbingan belajar berbasis computer tentang strategi mengatasi stress belajar. [online].

Alvin, N. 2007. Handling study stress: Panduan agar anda bisa belajar bersama anak-anak anda. Jakarta: elex media komputindo.

An. (2003). Stress berdampak pada pikiran, emosi dan perilaku seseorang.

Anwar Prabu Mangkunegara, (2002)., Manajemen sumber daya manusia, PT. remaja rosda Karya, Bandung

Feldman, R.S. (1989). Adjustment : Applying Psychology in Complex World. New York : Mc Graw-Hill.

Goleman, D. (2000). Emotional Intelligence (terjemahan),Jakata : Gramedia Pustaka Utama.

Goleman, D. (2002). Working With Emotional Intelligence (terjemahan). Jakarta : PT. Gramedia Pustaka Utama

Goleman,D. (2001). Kecerdasan emosional untuk mencapai puncak prestasi (Terjemahan;widodo).,Jakarta: Gramedia Pustaka Utama.

Hadi, S. (2000). Metodologi research jilid I. Yogyakarta.

Hadi, S. 2006. Metodologi research jilid III. Yogyakarta

Health Psychology : Biopsychosocial Interactions. Third Edition. United States of American: John Wiley \& Sonc, Inc

http://eprints.uny.ac.id/9570/ [12 maret 2013].

Jeffrey ,S.Nevid .,Spencer, A.Rathus ., \&Greene. (2003). Psikologi Abnormal Jilid 2. Edsis Kelima.

Lusiawati. (2013). Kecerdasan emosi dan penyesuaian diri pada remaja awalyang tinggal dipanti asuhan uswatun hasanah Samarinda. e-journal psikologi, 167-176.

Ogder. (2000). Stress yang melibatkan Stressor, Yogya :Rineka Cipta

Patton, Patricia. 2002. EQ (Kecerdasan Emosional) Di Tempat Kerja. Jakarta: PT.

Pustaka Delapratasa.

Pinel, J.P.J., 2009. Stres dan kesehatan. dalam: Biopsikologi Edisi ke-7.

Yogyakarta: Pustaka Pelajar,

Rasmun, 2004. Pengertian stres, sumber stres, dan sifat stresor. dalam: stres, koping, dan Adaptasi Edisi ke-1. Jakarta: Sagung Seto, 9-26.

Sarafino, Ep. (2000). Health Psychology biopsychological interaction,New York: John Wiley and Sons.

72 
Hubungan Antara Kecerdasan Emosi Dengan Tingkat Stress Terhadap Program Wajib Asrama dan Pendidikan Semi Militer Pada Taruna Politeknik Ilmu Pelayaran Semarang Proyeksi, Vol. 14 (1) 2019, 63-73

Schafer, W. (2007). Stress management for wellnesss,4th ed,California:Wades Worth.

Seyle, H. 1976. Seyle's Guide to stress research. New York:

Sudaya, I W. 2014 E-journal, Management Stress, Universitas Pendidikan Ganesha, Jakarta (Vol.2)

Sugiono. (2008). Statistika untuk penelitian, Bandung: Alfabeta.

Sugiyono. (2013). Metode penelitian pendidikan kuantitatif, kualitatif, dan R\&D. Bandung ALFABETA

Stein, Steven J. Dan Book, Howard E.2000. Ledakan EQ: 15 Prinsip dasar kecerdasan emosional meraih sukses, Alih Bahasa: Trinada Rainy Januarsari. Bandung:Kaifa

Van Nostrand Rainhold. (2016) www.e-psychology/workstressor/. Retrieved. 2,

Walker, J.,(2002). Teens in Distress Stress Adolescent Stress and Depression, Minnesota University. Available From :

http://www.extension.umn.edu/distribution/youthdevelopment/DA3083.html[Accesed 4 March 2010]

Willkinson, E.G. (2002). Bimbingan dokter pada stress. Jakarta: Dian Rakyat

Wulandari, Pengaruh aromaterapi terhadap tingkat stress mahasiswa, Program S1 Psikologi Universitas Airlangga. 8, 2008 